\title{
Online Dispute Resolution Sebagai Model Perlindungan Hukum Pelaku Bisnis
}

\author{
Wahyu Beny Mukti Setiyawan, Erifendi Churniawan, Rudatyo \\ Fakultas HukumUniversitas Islam Batik Surakarta, Politeknik Perkeretaapian Indonesia, \\ Fakultas Hukum Universitas Islam Batik Surakarta \\ muktibeny@gmail.com
}

Submit: 28-06-2020; Review: 28-06-2020; Terbit: 28-06-2020

\begin{abstract}
The development of technology, information and communication has contributed greatly to the fulfillment of human needs, one of which is in the field of online commerce or what is more commonly referred to as e-commerce. Ecommerce provides many advantages for the community, one of which is the community can conduct transactions without having to meet. The complexity of activities in e-commerce does not rule out the possibility that e-commerce will cause various kinds of disputes. Therefore, a fast and safe dispute resolution model that protects the interests of the parties is needed. This research is a normative study, using the statute approach and concept approach. To resolve this e-commerce dispute, a fast dispute resolution model is needed. This is because if a business dispute is too long to be ignored, it will lead to lower productivity and hamper economic progress and prosperity. Therefore, the idea of using an online dispute resolution (ODR) system as an effort to resolve disputes quickly and protect the interests of the disputing parties in e-commerce transactions.
\end{abstract}

Keywords: Online Dispute Resolution, Legal Protection, Business Actors.

\begin{abstract}
Abstrak
Perkembangan teknologi, informasi, dan komunikasi telah memberikan kontribusi yang besar bagi pemenuhan kebutuhan manusia, salah satunya di bidang perdagangan online atau yang lebih sering disebut dengane-commerce. E-commerce memberikan banyak kelebihan bagi masyarakat, salah satunya adalah masyarakat dapat melakukan transaksi tanpa harus bertemu. Kompleksnya aktivitas dalam e-commerce tersebut tidak menutup kemungkinan bahwa e-commerce akan menimbulkan berbagai macam sengketa. Oleh sebab itu, diperlukanlah model penyelesaian sengketa yang cepat dan aman yang melindungi kepentingan para pihak. Penelitian ini termasuk penelitian normatif, dengan menggunakan pendekatan perundang-undangan dan pendekatan konsep. Untuk menyelesaikan sengketa e-commerce ini diperlukan suatu model penyelesaian sengketa yang cepat. Hal ini disebabkan apabila sengketa bisnis terlalu lama untuk dibiarkan maka akan menimbulkan menurunkan produktivitas serta menyebabkan terhambatnya kemajuan dan kesejahteraan ekonomi. Oleh sebab itu, gagasan untuk menggunakan sistem online dispute resolution (ODR)
\end{abstract}


sebagai upaya penyelesaian sengketa yang cepat dan melindungi kepentingan para pihak yang bersengketa dalam transaksi e-commerce.

\section{Kata Kunci: Online Dispute Resolution, Perlindungan Hukum, Pelaku Bisnis.}

\section{Pendahuluan}

Perkembangan teknologi, informasi, dan komunikasi telah memberikan kontribusi yang signifikan terhadap pemenuhan kebutuhan masyarakat. Bahkan, Pengguna internet di Indonesia telah mencapai 132.7 juta orang dimana pengguna terbanyak sejumlah 86.3 juta orang ada di pulau Jawa dan kedua di Sumatera (Indonesia, 2016). Sebanyak 132,7 juta pengguna internet memanfaatkan internet untuk media sosial ( $97.4 \%)$, hiburan $(96.8 \%)$, berita $(96.4 \%)$, pendidikan (93.8\%), komersial (93.1\%), dan layanan publik (91.6\%) (Margaretha Rosa Anjani, Budi Santoso, 2018). Potensi ini kemudian dimanfaatkan dengan munculnya sebuah model transaksi bisnis yang disebut e-commerce yang memiliki keunggulan yakni, inovatif, kreatif dan mengikuti hight-tech improvement (kemajuan teknologi tinggi) (Arsyad Sanusi, 2001).
Melalui e-commerce, transaksi dapat dilakukan tanpa harus bertemu. Transaksi seperti pembayaran dan data message yang berisi perjanjian bisa disampaikan oleh pihak terkait melalui internet (Arsyad Sanusi, 2001). Indonesia merupakan pasar e-commerce terbesar di Asia Tenggara dengan platform belanja online lokal yang tetap mendominasi lanskap industry e-commerce (Https : //money. kompas.com/read/2019/08/26/1222 18226/e-commerce-apa-yangpimpin-pasar-indonesia). Dalam transaksi tersebut, dapat melibatkan hubungan yang meliputi, business to business, business to customer, atau customer to customer, customer to business, dan intra business (organizational) electronic commerce (Moch. Basarah, 2011).

Kompleksnya aktivitas dalam e-commerce tersebut tidak menutup kemungkinan terjadinya sengketa dalam bertransaksi, seperti masalah harga, kualitas barang dan jangka 
waktu pengiriman (Rochani Urip Salami, Rahadi Wasi Bintoro, 2013). Perselisihan dan pertikaian transaksi bisnis yang menggunakan e-commerce tersebut disebabkan oleh adanya wanprestasi dan perbuatan melawan hukum dari salah satu pihak. Karena adanya sengketa tersebut menimbulkan kerugian, maka dibutuhkan mekanisme penyelesaian sengketa yang dapat melindungi kepentingan para pelaku bisnis ini. Secara umum, penyelesaian sengketa dapat dilakukan dengan litigasi maupun non-litigasi (Bambang Sutiyoso, 2008).

Di dalam dunia bisnis saat ini, penyelesaian sengketa melalui pengadilan tidak disukai oleh banyak pihak terutama kalangan pelaku bisnis dan kalaupun akhirnya penyelesaian dilakukan melalui lembaga peradilan, hal ini sematamata hanya sebagai jalan terakhir (ultimum remedium) setelah upaya lain tidak membuahkan hasil (Adel Chandra, 2014). Sharyn Roach Anleudari Flinders University (Australia), dalam bukunya juga menyatakan bahwa sejak tahun tujuh puluhan, para kritikus dan pembaharu hukum menyatakan bahwa sangat tidak memadai menyerahkan semua penyelesaian perkara kepada pengadilan. Hal tersebut akan berakibat pada penumpukan perkara di pengadilan yang akan membuat penyelesaian sengketa menjadi lama dan memakan banyak biaya. Hal ini tentu bertentangan dengan asas berperkaraya itu, sederhana, cepat dan berbiaya ringan.

Adanya ketidakpuasan terhadap proses pengadilan tersebut melandasi terbentuknya mekanisme penyelesaian sengketa melalui nonlitigasi (Sudjana, 2018). Mekanisme penyelesaian sengketa non-litigasi ini diatur dalam Undang-Undang No. 30 Tahun 1999 tentang Arbitrase dan Alternatif Penyelesaian Sengketa. Mekanisme penyelesaian sengketa non-litigasi meliputi arbitrase, konsultasi, negosiasi, mediasi, konsiliasi, atau penilaian ahli. Salah satu yang populer dan diminati kini adalah cara penyelesaian sengketa melalui arbitrase (Rahmadi Indra Tektona, 2011). Arbitrase dianggap bentuk 
penyelesaian sengketa alternatif yang utama bila dilihat dari sifat yudisialnya, syarat-syarat dan proses yang dapat dipergunakan, karakter yang mengikat dan kemudahan pelaksanaan hasilnya, serta bantuan secara hukum yang diwajibkan kepada pengadilan dalam prosedur pelaksanaan putusan arbitrase (Abdul Halim Barkatullah dan Syahrida, 2015)..

Kemudian seiring dengan perkembangan teknologi yang menuntut kecepatan, maka timbulnya sengketa secara online melalui transaksi e-commerce tersebut diharapkan agar dapat diselesaikan juga secara online. Mekanisme penyelesaian sengketa non-litigasi secara online, diharapkan memberikan banyak keuntungan, salah satunya adalah kemudahan untuk menyelesaikan sengketa untuk para pihak yang tidak berada dalam satu wilayah (Lintang Tantowi, 2015). Praktik penyelesaian sengketa secara online ini dikenal dengan istilah online dispute resolution (ODR) (Meline Gerarita Sitompul, 2016). Sistem ini mengadopsi metode penyelesaian sengketa melalui APS yang prosedur penyelesaian sengketanya dilaksanakan secara online dengan media teknologi informasi sebagai "fourth party" untuk pihak-pihak yang bersengketa dalam berkomunikasi. Karena dapat menyelesaikan sengketa tanpa bertatap muka, maka praktik ODR ini cocok digunakan untuk penyelesaian sengketa $e$-commerce yang bersifat cross-border (Dr Pablo Cortez, 2014).

Melalui ODR ini, arbitrase dapat memberikan harapan yang besar untuk penyelesaian sengketa para pelaku bisnis karena dinilai lebih efektif. Meski belum populer di Indonesia, ODR sudah diterapkan di beberapa negara, diantaranya seperti European Union (EU) (Hudiyanto, 2017), American Arbitration Association (AAA), dan China International Economic and Trade Arbitration Commission (CIETAC). Penerapan ODR di negara-negara tersebut memiliki kesamaan yaitu untuk menyelesaikan sengketa yang disebabkan oleh transaksi lintas batas negara yang dilakukan secara 
elektronik. Namun, dalam merespon adanya hal tersebut, pemerintah belum membentuk peraturan hukum yang secara spesifik menjelaskan tata cara untuk para pelaku bisnis dalam menyelesaikan sengketa $e$ commerce secara jelas dan terstruktur.. Padahal, dalam Peraturan Presiden No.74 Tahun 2017 tentang Peta Jalan Sistem Perdagangan Nasional Berbasis Elektronik (Road Map ECommerce), target keluaran pemerintah adalah skema penyelesaian sengketa berbasis online (Online Dispute Resolution) (Peraturan Presiden Nomor 74 Tahun 2017). Adagium het rechthink achter de feitenaan, yang berarti bahwa hukum berjalan tertatih-tatih di belakang sebuah peristiwa, tepat menggambarkan kondisi hukum tersebut.

Kekosongan hukum mengenai ODR dapat menjadi suatu hambatan dalam penerapan ODR di Indonesia. Dalam era serba digital ini pembuat undang-undang harus selalu berusaha untuk mengejar perkembangan khususnya dalam bidang teknologi informasi
(Katherine L. Lynch, 2003) mengingat inovasi dan perubahan sangat cepat terjadi dan membuat hal tersebut menyulitkan pembuat undang-undang untuk menyusun dan menetapkan peraturan yang efektif karena sifat dari hukum yang berkaitan dengan teknologi tersebut sejatinya memiliki jangka waktu hidup yang singkat (Nicholas W. Allard \& David A. Kass, 1997). Berdasarkan yang sudah diuraikan diatas perlu sebuah pengaturan dan model untuk menjamin pelaku usaha atau bisnis dalam menyelesaikan sengketa, sehingga bagaimanakah pengaturan Online Dispute Resolution Sebagai Model Perlindungan Hukum Pelaku Bisnis?

\section{Metode Penelitian}

$$
\begin{aligned}
& \text { Penelitian Hukum (legal } \\
& \text { research) dalam bahasa Belanda } \\
& \text { disebut rechtsonderzoek (Peter } \\
& \text { Mahmud Marzuki, 2016). Penelitian } \\
& \text { ini menggunakan penelitian hukum } \\
& \text { normatif. Penelitian hukum } \\
& \text { normative adalah penelitian yang } \\
& \text { dilakukan dengan cara meneliti }
\end{aligned}
$$


berdasarkan data-data sekunder atau data kepustakaan.

Ditinjau dari sifatnya penelitian ini termasuk penelitian hukum yang bersifat deskriptif, maksudnya adalah suatu penelitian yang dimaksudkan untuk memberikan data-data yang seteliti mungkin tentang manusia, keadaan atau gejala lainnya. Penelitian ini bertujuan untuk menemukan sebuah pengaturan dan model untuk menjamin pelaku usaha atau bisnis dalam menyelesaikan sengketa.

Bentuk penelitian ini merupakan penelitian evaluatif, yaitu untuk mengetahui dan mengkaji bagaimanakah pengaturan online dispute resolution sebagai model perlindungan hukum pelaku bisnis.

Penelitian ini menggunakan pendekatan kualitatif. Menurut Soerjono Soekanto, pendekatan kualitatif adalah suatu penelitian yang menghasilkan data deskriptif analisis, yaitu apa yang dinyatakan responden secara tertulis atau lisan dan juga perilaku nyata, yang diteliti dan dipelajari sebagai sesuatu yang utuh.

Dalam penelitian ini, digunakan teknik studi pustaka yaitu, mempelajari buku-buku, literatur, peraturan perundang-undangan, jurnal penelitian, hasil penelitian terdahulu dan bahan kepustakaan lain yang berkaitan dengan masalah yang sedangdikaji.

\section{Hasil dan Pembahasan}

Model Perlindungan Hukum Pelaku Bisnis

Dalam ODR memang terdapat beberapa mekanisme penyelesaian sengketa layaknya pada alternative penyelesaian sengketa yang mana terdiri atas prosedur negosiasi, konsolidasi, mediasi, arbitrase, dan yang lainnya, akan tetapi dalam pembahasan ini akan difokuskan pada pembahasan mengenai ODR pada prosedur online arbitration. Online arbitration yang berakar pada arbitrase sememiliki sifat putusan akhir yang berisifat final dan mengikat (M. Husseyn Umar dan A. Supriyani Kardono, 1995). Dengan demikian, putusan arbitrase lebih memiliki kepastian hukum bagi para pihak dibandingkan bentuk penyelesaian sengketa nonlitigasi yang lain dan hal tersebut membuat pelaku bisnis merasa lebih 
aman dan terjamin. Melihat praktik arbitrase di Indonesia yang belum efektif dan efisien sehingga ODR dibutuhkan bagi pelaku $e$ commerce (Otoritas Jasa Keuangan, 2017), tetapi pelaksanaan ODR sendiri tidak bisa asal diterapkan begitu saja di Indonesia mengingat sistem hukum di Indonesia yang memiliki norma dan asas yang tidak dapat disimpangi. Oleh karena itu, dibutuhkan suatu peraturan perundang-undangan khusus yang mengatur mengenai pelaksanaan ODR untuk menjamin bahwan antinya ODR dilaksanakan sesuai dengan arah pembangunan hukum nasional serta norma dan asas hukum yang berlaku.

Dalam peraturan perundangundangan tersebut nantinya harus memuat beberapa hal, yaitu:

1) Asas dan prinsip pelaksanaan ODR;

2) Sistem ODR yang telah disesuaikan dengan ketentuan hukum di Indonesia;

3) Aspek keamanan sebagai bentuk dari perlindungan pengguna pada ODR.
Seperti yang telah diuraikan bahwa jika ingin menerapkan praktik ODR di Indonesia maka harus memperhatikan norma hukum yang telah ada sehingga tidak dapat begitu saja mengadopsi praktik sistem ODR seperti yang digunakan di negara maju seperti Australia, Inggris, Amerika, dan lain lain. Sistem hukum yang dianut oleh negara-negara yang terlebih dahulu memiliki sistem ODR tersebut berbeda dengan Indonesia, berdasarkan klasifikasi yang disusun oleh Rene David dan John E.C. Brierly (Ida Keumala Jeumpa, 2014) yang mana sebagian besar negara-negara tersebut menganut bahwa sistem hukum Anglo-Saxon (common law) dimana hukum berasal dari kebiasan dan putusan hakim, sedangkan Indonesia yang menganut Eropa Kontinental (civil law) dengan karakteristik bahwa hukum tertulis (peraturan perundang-undangan) menjadi pedoman atau sumber hukum yang utama sehingga setiap perbuatan harus didasarkan pada pedoman atau sumber hukum berupa peraturan perundang-undangan 
tersebut. Dalam hal ini, apabila sistem ODR yang telah berlaku di negara lain tersebut ingin diadopsi untuk diterapkan di Indonesia maka hal harus dilakukan transplantasi hukum terlebih dahulu, yang berarti menyesuaikan dengan kecenderungan hukum dari system hukum common law ke sistem hukum Indonesia dan memperhatikan nilai--nilai Pancasila (Hari Purwadi dan Adriana Grahani Firdausy, 2015).

Dalam proses penyelesaian sengketa non-litigasi yang sebagai dasar pembentukan ODR memiliki beberapa asas-asas yang mengatur pelaksanaan penyelesaian sengketa non litigasi itu sendiri, yaitu :

1) Proses sederhana, cepat, dan biaya ringan, system penyelesaian sengketa sederhana, cepat, dan biaya ringan merupakan asas dalam system peradilan Indonesia, namun praktiknya karena berhadapan dengan sistem lain yang membuat proses penyelesaian berlarut-larut (M. Yahya Harahap, 1997) sehingga asas ini diterapkan dalam proses penyelesaian sengketa non-litigasi termasuk arbitrase, karena memang proses dalam hal ini lebih singkat dari proses litigasi, terkait biaya yang hanya digunakan untuk kepentingan pihak ketiga pun lebih murah dibanding biaya beracara dalam proses litigasi, dan prosedur arbitrase yang diserahkan kepada para pihak memakan waktu yang lebih singkat mengingat para pihak merupakan pebisnis yang mempertimbangkan waktu dengan baik. Asas ini harus terimplementasikan dengan baik dalam ODR karena mengingat pula bahwa sifat online dalam ODR yang seharusnya mendukung pelaksanaan asas ini.

2) Kebebasan berkontrak, asas ini sebenarnya berasal dari hukum perdata tepatnya pada Pasal 1338 Ayat (1) Kitab Undangundang Hukum Perdata yang memiliki arti pemberian kebebasan kepada para pihak untuk mengatur sendiri atau 
menentukan aturan hukumnya sendiri yang berlaku terhadap hak dan kewajiban hukum kontraktual (Sutan Remy Sjahdeni, 1993) termasuk memberikan kebebasan untuk mencantumkan klausul penyelesaian sengketa di luar pengadilan dalam rangka mendukung kegiatan bisnis dan perdagangan yang lebih kondusif dan berkelanjutan (sustainable), karena hamper dipastikan tidak sedikit kontrak yang dibuat dan dilaksanakan oleh pihak-pihak yang membuat kontrak, memiliki kendala dalam pelaksanaannya (Maulidiazeta Wiriardi, 2011) termasuk bebas untuk menyelesaikan sengketa melalui sistem ODR.

3) Konsensualisme, kesepakatan antar para pihak juga diperlukan dalam proses penyelesaian sengketa arbitrase karena pada prinsipnya, suatu sengketa tidak dapat diselesaikan melalui arbitrase tanpa adanya kesepakatan dan kesukarelaan para pihak
(Christopher W. Moore, 1995) sehingga sifat dari ODR pun mengikuti hal tersebut yang mana ODR tidak dapat digunakan jika para pihak tidak terlebih dahulu sepakat untuk menyelesaikan sengketa melalui layanan ODR.

4) Itikad baik, asas ini memang disebutkan dalam UU No. 30 Tahun 1999 tentang Arbitrase dan Alternatif Penyelesaian Sengketa, namun tidak diatur lebih lanjut maupun didefinisikan apa yang dimaksud itikad baik tersebut (Djaja S. Meliala, 1987). Asas Itikad baik dalam penyelesaian sengketa dapat ditafsirkan sebagai sikap atau perbuatan lahiriyah para pihak yang memberikan keterangan, alat bukti, dan mendukung jalannya proses penyelesaian sengketa dengan baik dan sejujurjujurnya (Novran Harisa, 2018).

5) Pacta Sunt Servanda, yang memiliki arti asas yang paling mendasar dalam konteks pembuatan dan pelaksanaan suatu perjanjian yang berlaku 
secara universal. Asas ini mengikat para pihak pasca tercapainya suatu kesepakatan yang mengikat para pihak yang membuat kesepakatan tersebut (Harry Purwanto, 2009) hal ini memiliki arti bahwa apabila para pihak telah sepakat untuk menyelesaikan sengketa melalui proses arbitrase maka hal tersebut harus dilakukan, begitu pula dengan hasil dari proses tersebut.

Selain terdapat asas dasar dalam pelaksanaan arbitrase melalui ODR terdapat juga beberapa prinsip pelaksanaan penyelesaian sengketa ODR, yaitu :

1) Kerahasiaan dalam proses, karena mengingat sifat dari arbitrase sendiri merupakan proses yang bersifat privat antar pihak saja maka proses arbitrase dalam ODR juga harus menjamin kerahasiaan proses penyelesaian sengketa terbatas hanya untuk para pihak saja.

2) Perlindungan pelaku bisnis, penyelenggaraan ODR dimaksudkan untuk memberikan rangsangan bagi pelaku bisnis dalam hal adanya jaminan bahwa sengketa yang terjadi dapat teratasi dengan lebih cepat, sederhana dan berbiaya ringan.

3) Transparansi mekanisme, transparansi dalam hal ini berarti bahwa layanan ODR harus memberikan informasi mengenai prosedur atau mekanisme penyelesaian sengketa kepada para pihak untuk menghindari kesalahdugaan bagi para pihak yang ingin menyelesaikan sengketa melalui ODR.

4) Kesetaraan pihak, hal ini bertujuan untuk melindungi pengguna yang memiliki posisi lebih lemah dimana dalam ODR semua pihak akan memiliki posisi yang setara.

5) Keamanan sistem, dalam penyelenggaraan ODR yang menggunakan internet sebagai basisnya maka diperlukan jaminan mengenai keamanan layanan.

Pihak yang bersengketa merupakan salah satuaspek yang paling penting dalam ODR karena 
pihak inilah yang menjadi subyek sekaligus pengguna sistem ODR. Layaknya penyelesaian sengketa perdagangan pada umumnya yang mana para pihak merupakan penjual dan pembeli yang mana salah satu diantara pihak tersebut merasa pihak lain tidak memenuhi kewajiban atau melakukan sesuatu yang tidak diperjanjikan yang menimbulkan kerugian pada pihak lainnya (Priyatna H. Abdurrasyid, 2002), dalam ODR para pihak juga memiliki definisi yang sama, akan tetapiperbedaannya terdapat pada subyek tersebut merupakan penjual dan pembeli dalam e-commerce sebagai pengguna atau pihak pertama. Selain terdapat pihak yang bersengketa terdapat pula penyelenggara yang melakukan pengembangan, penyediaan, dan pengoperasian sistem layanan ODR yang merupakan pihak swasta maupun lembaga pemerintah yang menyediakan layanan penyelesaian sengketa. Pada hakekatnya penyelesaian sengketa non-litigasi selain terdapat para pihak yang bersengketa terdapat juga pihak ketiga yaitu arbiter dan dalam ODR arbiter masih memegang peran penting tidak serta merta tergantikan oleh teknologi.

Terdapat tiga model sistem ODR (Goodman dan Joseph W, 2016) yang saat ini berkembang di dunia yaitu fully automated cyber negotiation, using software and fasilitator, dan, using online technology. Di Indonesia sendiri memang belum ada regulasi yang mengatur mengenai sistem ODR makadari itu dapat ditinjau dari regulasi yang mengatur sistem arbitrase dalam Undang-Undang No. 30 Tahun 1999 tentang Arbitrase dan Alternatif Penyelesaian Sengketa sebagai induk atau asal dari ODR. Dalam pemilihan model sistem ODR yang mendekati model arbitrase konvensional selayaknya yang diatur dalam undang-undang tersebut adalah model using online technology. Model ini menggunakan teknologi online seperti e-mail, instant messaging, chat rooms dan video conference sebagai media penghubung proses penyelesaian sengketa. Proses penyelesaiannya sama seperti proses 
penyelesaian sengketa secara konvensional dengan memilih pihak ketiga sebagai medium penyelesaian sengketa. Model ini dianggap sesuai untuk diterapkan di Indonesia mengingat bahwa penyelesaian sengketa masih harus terdapat pihak ketiga arbiter diantara para pihak yang dinyatakan secara expressive verbis dalam undang-undang tersebut pada Pasal 6 Ayat (3) dan (4).

Pasal 6 Undang-Undang No. 30 Tahun 1999 tentang Arbitrase dan Alternatif Penyelesaian Sengketa :

(3). "Dalam hal sengketa atau beda pendapat sebagaimana dimaksud dalam ayat (2) tidak dapat diselesaikan, maka atas kesepakatan tertulis para pihak, sengketa atau beda pendapat diselesaikan melalui bantuan seorang atau lebih penasehat ahli maupun melalui seorang mediator".

(4). "Apabila para pihak tersebut dalam waktu paling lama 14 (empat belas) hari dengan bantuan seorang atau lebih penasehat ahli maupun melalui seorang mediator tidak berhasil mencapai kata sepakat, atau mediator tidak berhasil mempertemukan kedua belah pihak, maka para pihak dapat menghubungi sebuah lembaga arbitrase atau lembaga alternatif penyelesaian sengketa untuk

$$
\text { menunjuk }
$$$$
\text { mediator". }
$$

seorang

Hal ini selaras dengan praktik dalam model using online technology yang secara sederhana hanya mengubah media yang dapat mempertemukan para pihak dari yang sebelumnya harus bertemu secara langsung bertatap muka maka dengan model ini difasilitasi secara online dengan memanfaatkan teknologi untuk bertatap muka secara tidak langsung. Dalam system elektronik yang mana para pengguna tidak bertatap muka dan berinteraksi secara langsung maka para pengguna tersebut hanya dapat mengandalkan trust atau kepercayaan untuk melakukan transaksi atau perbuatan tertentu, akan tetapi kepercayaan itu sendiri tidak dapat didapatkan begitu saja karena harus dibangun oleh penyedia layanan salah satunya dengan memberikan jaminan keamanan bagi pengguna. Pada sistem ODR pun penyedia layanan harus memberikan jaminan keamanan data dan kerahasiaan bagi para pihak yang ingin melakukan penyelesaian sengketa. Di Indonesia 
sendiri terdapat beberapa metode yang diterapkan untuk menjamin kerahasiaan dan keamanan sebuah sistem elektronik yang salah satunya adalah dengan menerbitkan sertifikasi keamanan yang diterbitkan oleh pihak yang berwenang ataupun lembaga pemerintah. Pada prinsipnya, aspek keamanan dalam ODR harus memenuhi kriteria keamanan berikut :

1) Keamanan Informasi, dalam hal ini mengacu pada keamanan dalam proses ODR dalam melindungi informasi para pihak agar tidak tersebar keluar platform ODR, keamanan informasi ini juga merupakan kewajiban bagi arbiter atau pihak ketiga untuk meyakinkan para pihak untuk memberikan seluruh informasi yang relevan tanpa ada yang dirahasiakan untuk mendukung proses penyelesaian sengketa;

2) Keamanan Data, pada konteks ini berfokus pada proteksi dalam sistem komunikasi, perangkat lunak dan keras hingga server yang digunakan dalam ODR (Elisabeth WilsonEvered, 2012). Bentuk proteksi ini bertujuan untuk mencegah pihak luar untuk meretas sistem dan mendapat informasi yang bersifat privasi, yang mana berkaitan dengan sengketa seperti gambar alat bukti pendukung yang diunggah maupun yang tidak berkaitan langsung dengan sengketa seperti data pribadi para pihak. Selain itu, berfokus pada aspek keamanan ini akan membuat penyelenggara untuk menetapkan batasan internal dalam rangka untuk memastikan bahwa pihak yang tidak berkepentingan tidak akan bisa mengakses informasi yang bersifat privat.

3) Keamanan Personal, dalam konteks ini keamanan dikonotasikan dengan ketentuan proses yang aman dan didefinisikan secara jelas untuk melindungi pengguna dari kerugian atau bahaya, baik secara fisik atau emosional. Dalam ODR, risiko kerugia nsecara fisik terhitung sangat 
rendah kemungkinan terjadinya karena para pihak sendiri tidak bertemu secara fisik. Dengan tidak adanya kehadiran secara langsung dari para pihak dalam proses penyelesaian sengketa membuat tidak adanya risiko gejolak emosional dan bahayabahaya fisik lain yang dapat mengancam para pihak tidak seperti saat mereka melakukan penyelesaian sengketa dengan bertemu langsung.

4) Keamanan Sistem, hal ini berkaitan dengan sejauh mana pengguna merasa yakin bahwa layanan ODR yang mereka gunakan tidak memanfaatkan informasi, partisipasi, perilaku atau data mereka dengan cara apa pun. Pengguna akan merasa bahwa sistem ODR yang digunakan tersebut aman selama tidak merasa layanan tersebut menggunakan ataupun menjual datanya, selain itu penyelenggara ODR juga harus memperhatikan beberapa hal terkait keamanan bagi pengguna, antara lain: menggunakan data tanpa izin pengguna, menggunakan data dengan cara yang tidak disukai, data mining untuk tujuan apa pun, mempelajari perilaku konflik dan penggunaan data lainnya (Noam Ebrer, 2015).

Dalam aspek keamanan selain harus memenuhi beberapa prinsip di atas, penyelenggara juga harus memiliki fasilitas data disaster recovery plan yang terwujud dalam suatu data center (pusat data) dan disaster recovery center (pusat pemulihan bencana) yang merupakan rencana dan langkahlangkah untuk menggantikan dan/atau memulihkan kembali akses data, perangkat keras dan perangkat lunak yang diperlukan, agar penyelenggara dapat menjalankan kegiatan operasional yang kritikal setelah adanya gangguan dan/atau bencana (Jon William Toigo, 1989). Keberadaan data discovery recovery plan bagi penyelenggara ODR merupakan suatu keharusan mengingat ODR merupakan layanan yang berbasis pada jaringan internet yang mana terdapat risiko untuk terjadinya bencana data seperti pencurian data, peretasan, gangguan 
jaringan, dan bencana data lain yang dapat mengancam data pribadi pengguna maupun data terkait sengketa pengguna.

\section{Simpulan}

Perkembangan e-commerce yang pesat belum diimbangi dengan pengaturan yang jelas dan terstruktur. Terlihat dari belum diaturnya model penyelesaian sengketa e-commerce untuk para pelaku usaha yang menyebabkan ketidakpastian hukum dalam pelaksanaannya. Online dispute resolution merupakan sebuah metode penyelesaian sengketa $e$ commerce yang ideal untuk menjamin kepastian hukum bagi para pelaku bisnis dalam menyelesaikan sengketa secara efektif dan efisien dengan tidak mengesampingkan asas berperkara di pengadilan yaitu sederhana, cepat, dan berbiaya ringan. Perlu dibentuk Peraturan Pemerintah sebagai bentuk pelaksanaan dari Undang-Undang Nomor 7 Tahun 2014 tentang Perdagangan yang mengatur lebih lanjut mengenai penyelesaian sengketa melalui online dispute resolution demi memberikan jaminan dan perlindungan hukum bagi pelaku bisnis online dalam hal apabila terjadi sengketa. Membuat standarisasi sistem dari online dispute resolution yang telah disesuaikan dengan ketentuan hukum yang ada di Indonesia sehingga praktik online dispute resolution dapat dilaksanakan di Indonesia tanpa menyalahi kaidah hukum positif terkait penyelesaian sengketa.

\section{Daftar Pustaka}

\section{Buku}

Abdurrasyid, Priyatna H, 2002. Arbitrase dan Alternatif Penyelesaian Sengketa, Jakarta :Fikahati Anesta.

Barkatullah, Abdul Halim, Syahrida, 2009, Sengketa Transaksi E-Commerce Internasional, Bandung : Nusa Media.

Basarah, Moch., 2011, Arbitrase Tradisional dan Modern (Online), Yogyakarta : GentaPublishing

Harahap, M. Yahya, 1997, Beberapa Tinjauan Mengenai Sistem Peradilan dan Penyelesaian Sengketa, Bandung : PT. Citra Aditya Bakti.

Hudiyanto, et. al. 2017, Kajian Perlindungan Konsumen 
Sektor Jasa Keuangan : Online Dispute Resolution, Jakarta : Departemen Perlindungan Konsumen OJK.

Kamal, Farizal F., 1999, Cyber Business, Jakarta : Elex Media Komputindo.

Lynch, Katherine L, 2003, The Forces Of Economic Globalization

:Challenges To The Regime Of International Commercial Arbitration, The Hague : Kluwer Law International.

Manan, Bagir, 2005, Pembangunan Hukum Oleh Masyarakat Melalui Penyelesaian Sengketa di Luar Proses Peradilan, Bandung : PT. Citra Aditya Bakti.

Meliala, Djaja S, 1987, Masalah Itikad Baik dalam KUHPerdata,

Bandung:Binacipta.

Moore, Christopher W., 1995, Mediasi Lingkungan, Jakarta: Indonesia Center for Environmental Law dan CDR Associates.

Sjahdeni, Sutan Remy, 1993, Asas Kebebasan Berkontrak dan Perlindungan yang Seimbang bagi Para Pihak dalam Perjanjian Kredit Bank di Indonesia.
Jakarta : Institut Bankir Indonesia.

Suparni, Niniek, 2001, Masalah Cyberspace Problematika Hukum dan Antisipasi Pengaturannya, Jakarta : Fortun Mandiri Karya.

Tantowi. Lintang, 2011, Penyelesaian Sengketa Melalui Arbitrase Secara Online di Indonesia, Jakarta : PT. Raja Grafindo Persada.

Toigo, Jon William, 1989, Disaster Recovery Planning, Managing Risk \& Catastrophe in Information Systems. New York : Yourdon PressComputing Series.

Umar, M. Husseyn dan A. Supriyani Kardono, 1995, Hukum dan Lembaga Arbitrase di Indonesia, Jakarta : Komponen Hukum Ekonomi ELIPS Project.

Usman, Rachmadi, 2010, Pilihan Penyelesaian Sengketa di Luar Pengadilan, Bandung : PT. Citra Aditya Bakti.

\section{Peraturan Perundang-Undangan}

Undang-Undang Dasar Negara Republik Indonesia Tahun 1945. 
Undang-Undang Republik Indonesia Nomor 30 Tahun 1999 tentang Arbitrase dan Alternatif Penyelesaian Sengketa.

Undang-Undang Republik Indonesia Nomor 19 Tahun 2016 perubahan atasUndangUndang Nomor11 Tahun 2008 tentang Informasi dan Transaksi Elektronik.

Peraturan Presiden Nomor 74 Tahun 2017 tentang Peta Jalan Sistem Perdagangan Nasional Berbasis Elektronik (Road Map ECommerce) Tahun 20172019.

\section{Artikel dan Jurnal}

Allard, Nicholas W \& David A. Kass, 1997, "Law and Order in Cyberspace." Washington Report.

Chandra, Adel, 2014 , "Penyelesaian Sengketa Transaksi Elektronik Melalui Online Dispute Resolution (ODR) Kaitan dengan UU No. 11 Tahun 2008 Informasi dan Transaksi Elektronik", Jurnal Ilmu Komputer. Vol. 10, No. 2, September.

Ebrer, Noam, 2013, "Fairness, Trust and Security in Online Dispute Resolution", Hamline University's School of Law's Journal of Public
Law and Policy, Vol. 36, Issue 2..

Elisabeth Wilson-Evered et al, Towards an On-Line Family Dispute Resolution Service in Australia, in Mobile Technologies For Conflict Management.

Goodman, Joseph W., n. d., The Pros and Cons of Online Dispute Resolution. an Assessment of CyberMediation Websites.

Harisa, Novran, 2018, “Asas Itikad Baik Dalam Perjanjian Arbitrase sebagai Metode Penyelesaian Sengketa". Jurnal Hukum AKTUALITA, Vol. 1, No. 1, Juni.

Indrani, Sarah Meilita, Hernawan Hadi, 2017, "Keberadaan Arbitrase Online Sebagai Cara Penyelesaian Sengketa Bisnis di Indonesia (Studi Badan Arbitrase Nasional Indonesia Jakarta)", Privat Law, Vol. 5, No. 2, Juli - Desember.

Jeumpa, Ida Keumala, 2014, "Contempt of Court :Suatu Perbandingan Antara Berbagai Sistem Hukum", Kanun Jurnal Ilmu Hukum, No. 62, Th. XVI, April.

Kamil, Hutrin, M. Ali Mansyur, 2014, "Kajian Hukum 
Online Dispute

Resolution (ODR) di

Indonesia Berdasarkan

Undang-Undang No. 30

Tahun1999", Jurnal

Pembaharuan Hukum.

Vol. 1, No. 2, Agustus.

Margaretha Rosa Anjani, Budi

Santoso, 2018, "Urgensi

Rekonstruksi Hukum E-

Commerce di Indonesia,"

Jurnal Law Reform, Vol.

14, No. 1, Maret

Purwadi, Hari dan Adriana Grahani Firdausy, 2015, "Konsekuensi

Transplantasi Hukum terhadap Pancasila sebagai Norma Dasar dan Hukum Lokal," Jurnal Yustisia, Vol. 4, No. 1, Januari - April

Purwanto Harry, 2009, "Keberadaan Asas Pacta Sunt Servanda Dalam Perjanjian Internasional", Jurnal Mimbar Hukum, Vol. 21, No. 1, Februari.

Rahmadi Indra Tektona, 2011, "Arbitrase Sebagai Solusi Penyelesaian Sengketa Bisnis di Luar Pengadilan." Jurnal Pandecta, Vol. 6, No. 1, Januari .

Salami, Rochani Urip, Rahadi Wasi Bintoro, 2013, "Alternatif Penyelesaian Sengketa dalam Sengketa Transaksi Elektronik (ECommerce)", Jurnal
Dinamika Hukum, Vol. 13, No.1, Januari.

Sanusi, Arsyad, 2001, "Transaksi Bisnis dalam Electronic Commerce $(E-$ Commerce) : Studi tentang Permasalahan Hukum dan Solusinya", Jurnal Hukum, Vol. 8, No. 16, Maret.

Sitompul, Meline Gerarita, M. Syaifuddin, dan Annalisa Yahanan, 2016, "Online Dispute Resolution $(O D R) \quad$ : Prospek Penyelesaian Sengketa $E$ Commerce di Indonesia". Jurnal Renaissance. Vol. 1, No.2, Agustus.

Sudjana, 2018, "Efektivitas dan Efisiensi Penyelesaian Sengketa Kekayaan Intelektual melalui Arbitrase dan Mediasi berdasarkan UndangUndang Nomor 30 Tahun 1999”. Ajudikasi :Jurnal Ilmu Hukum, Vol. 2, No. 1, Juni

Sutiyoso, 2008, Bambang. "Penyelesaian Sengketa Bisnis melalui Online Dispute Resolution dan Pemberlakuannya di Indonesia", Jurnal Mimbar Hukum, Vol. 20. No. 2, Juni.

Wiriardi, Maulidiazeta, 2011, "Prinsip-Prinsip Hukum Perjanjian Dalam Kesepakatan Para Pihak 
Yang Bersengketa Atas

Permohonan Intervensi

Pihak Ketiga Dalam

Undang-Undang Nomor

30 Tahun 1999 Tentang Arbitrase Dan Alternatif

Penyelesaian Sengketa". Yuridika, Vol. 26, No. 1, Januari - April.

\section{Internet/Website}

Https://www.baniarbitration.org/ina/ costs.php, diakses pada 19 Februari 2020 pukul 20.00 wib.

Https://money.kompas.com/read/201 9/08/26/122218226/ecommerce-apa-yangpimpin-pasar-indonesia, diakses pada 19 Februari 2020 pukul 20.10 wib. 